\title{
Violência e masculinidade nas relações de trabalho: imagens do campo em pesquisa etnográfica
}

\author{
Violence and Masculinity in Working Relations: Imagens from fieldwork
}

Rafael Alcadipani ${ }^{1}$

\begin{abstract}
Resumo
Este artigo analisa desenhos feitos por trabalhadores e que foram coletados durante uma pesquisa etnográfica de cerca de nove meses, conduzida por um dos autores deste estudo. Foram analisados 53 desenhos feitos por operadores de rotativas que produzem jornais em uma das maiores gráficas desse tipo na Europa. A empresa passava por uma grande mudança tecnológica, ao final da qual quatro de suas nove maiores máquinas foram substituídas. Como resultado, aproximadamente 65 trabalhadores ficaram sem trabalho. Além disso, ocorreu uma divisão entre os impressores que permaneceram no velho equipamento e aqueles que foram selecionados para o novo. As imagens desenhadas pelos trabalhadores expressam forte hostilidade, interpretada neste artigo a partir do conceito de violência simbólica de Bourdieu (1999). Essa violência está associada à sexualidade, à opressão e à autodestruição, condições essas articuladas com a dominação masculina e com as transformações decorrentes das mudanças ocorridas no espaço organizacional estudado. Nesse sentido, o artigo procura contribuir para uma maior compreensão das organizações, seja por destacar a relação entre masculinidade e violência simbólica nas empresas, seja por mostrar a possibilidade e a utilidade do emprego de métodos projetivos em pesquisa etnográfica. Além disso, ele aponta a necessidade de serem estudadas as diversas formas como a violência pode se manifestar no contexto organizacional.
\end{abstract}

Palavras-chave: violência; masculinidade; relações de trabalho; poder, desenhos.

\begin{abstract}
This paper aims to analyze sketches done by newspaper press operatives. The sketches analyzed in this article have been gathered during an in-depth ethnographic study carried out by one of this paper's author in one of the largest newspaper printing sites in Europe. The ethnographic study lasted for about 9 months. In this paper, we focus our discussion in 53 drawings done by press workers. The newspaper factory was undergoing a major technology change where four of its main newspaper presses were being replaced by state of arte machines. As a result, workers were made redundant at the same time that the remained workers were divided into 2 groups: those who were transferred to work in the brand new machines and those who were left to work in the old equipment. We will argue that the sketches content make explicit the symbolic violence pervasiveness in that organizational context which is associated with sexuality, oppression and selfdestruction. Such manifestations are also related to the changes that took place in the organization studied. Drawing on the work of Pierre Bourdieu, the paper seeks to make a theoretical contribution by highlighting that violence expressions are related to (management) male dominance that can threaten the shop-floor worker's sense of masculinity. Furthermore, the paper will also highlight the possibility of deploying projective methods in organizational research in order to have a deeper understanding of organizational realities.
\end{abstract}

Key words: violence; masculinity; working relations; power; drawings.

1 PhD in Business Administration - Manchester School of Management, The University of Manchester (Inglaterra). Professor Adjunto na Escola Administração de Empresas de São Paulo da Fundação Getulio Vargas - EAESP/FGV.Endereço: Rua Itapeva, 474 - 11 andar. São Paulo/SP - Brasil CEP:013132-000. E-mail: rafael.alcadipani@fgv.br

Artigo submetido em maio de 2008 e aceito em junho de 2009. 


\section{Introdução}

Não restam dúvidas de que a questão do poder foi amplamente abordada no contexto das relações de trabalho. De fato, trata-se de um tema clássico da área. Todavia, embora abordados, os pressupostos que constituem as práticas de poder e de dominação no contexto organizacional são um tema menos explorado nos estudos organizacionais. Historicamente, como nos mostra Foucault (1987), o exercício do poder está associado com manifestações da violência, e a questão da violência presente no ambiente de trabalho contemporâneo perpassa majoritariamente discussões a respeito de assédio moral no ambiente empresarial, geralmente, representado como uma anormalidade que precisa ser combatida (v. FREITAS, 2008; SOBOLL, 2008). Ou seja, há uma tendência de se analisar a presença da violência nas organizações contemporâneas como algo manifesto em relações pessoais perversas.

Nesse contexto, o objetivo deste artigo é sugerir e ilustrar como a violência está entranhada de uma maneira simbólica nas relações de trabalho. Para tanto, analisará dados coletados durante uma etnografia realizada em uma das maiores gráficas de jornais da Europa. O tema do artigo não surgiu como uma pergunta de pesquisa anterior à pesquisa empírica, mas, sim, emergiu como um dos temas importantes enquanto o autor deste artigo coletava dados na referida gráfica. A violência será abordada aqui através da discussão de 53 desenhos feitos por trabalhadores da organização pesquisada.

A empresa em estudo passava por uma grande mudança tecnológica, em que quatro de suas nove maiores máquinas estavam sendo substituídas. Como resultado, 65 trabalhadores ficaram sem trabalho, ao mesmo tempo em que ocorreu uma divisão entre os trabalhadores que permaneceram no velho equipamento e aqueles que foram selecionados para o novo. As imagens desenhadas pelos trabalhadores expressam forte hostilidade, interpretada neste artigo a partir do conceito de violência simbólica de Bourdieu (1999). Argumentaremos que essa violência está associada à sexualidade, à opressão e à autodestruição, condições essas articuladas à dominação masculina e às transformações decorrentes das mudanças ocorridas no espaço organizacional aqui descrito.

A seguir, o artigo discutirá a violência nas relações de trabalho, focando a questão da masculinidade. Mais adiante, apresentará a noção de violência simbólica. Depois, serão apresentados os procedimentos metodológicos do artigo e, na sequência, discutidos os desenhos feitos pelos trabalhadores da gráfica, seguindose algumas considerações finais.

\section{Violêncla nas relações de trabalho: a questão da mascullinidade}

Ao analisar as diferentes manifestações do poder punitivo, Foucault (1987) discute como o regime dos suplícios, caracterizado pelo poder de punir concentrado no soberano que o exercia de forma pública, nitidamente violenta e indiscriminada, transformou-se em algo inserido no contexto social de forma capilar e subliminar. Isto é, o pensador destaca a substituição do exercício da violência de forma clara e agressiva, como mecanismo de controle social, para uma preocupação com a garantia do controle por meio de sua diluição no tecido social, configurando-se como a ênfase disciplinar do poder de punir (FOUCAULT, 1987). Na verdade, isso não significa dizer que a violência não faça parte do regime disciplinar, mas sim que é praticada nesse contexto de forma controlada e pontual somente quando necessária para garantir a produção de corpos dóceis e submissos (v. FOUCAULT, 1987; PRESTES MOTTA, 1986). Dessa forma, Foucault (1987) destaca a fábrica como um local onde a disciplina está presente por excelência. Ele sugere que o exercício do poder moderno no contexto organizacional deixaria de lado a violência explícita, em nome de uma capilaridade do poder em contextos organizacionais específicos cujo foco é a maximização do potencial de trabalho dos indivíduos, algo impossível quando o regime do terror soberano impera. Nesse contexto, para Foucault (1987), as organizações são locais onde há o exercício da violência controlada que está imersa no tecido social. 
Nesse sentido, uma análise mais detalhada do contexto organizacional contemporâneo indicaria que a violência não está presente de forma marcante, mas sim que a sua presença é muito mais simbólica e subliminar do que explícita. A temática da violência nas organizações e nas relações de trabalho tem sido investigada por pesquisadores da área, como, por exemplo, Silva e Alcadipani (2004). Esses autores analisaram regimes de controle punitivos na Siderúrgica Rio-Grandense, a partir do referencial foucautiano, indicando que o controle organizacional nessa empresa migrou de formas onde a violência era clara e explícita para meios mais subliminares de controle. Segnini (1982), em seu estudo clássico, mostrou o papel da violência em regimes organizacionais disciplinares na ferrovia paulistana. No entanto, estudos nesse sentido ainda são incipientes em nosso país (como exceções, v. BICALHO, 2008; SIQUEIRA et al, 2008; SIQUEIRA; PRELORENTZOU, 2008).

$\mathrm{Na}$ literatura internacional, entretanto, encontram-se várias pesquisas sobre o tema. Por exemplo, Neuman e Baron (1998) tratam diretamente da violência e da agressividade no ambiente de trabalho com o objetivo de compreender atos de extrema violência que passaram a ser mais comuns em várias regiões dos EUA. Os autores apresentam três tipos de agressões que podem ocorrer no local de trabalho: i) formas brandas de agressividade, como falta de cooperação, rumores e fofocas que podem chegar até as expressões verbais mais duras; ii) discussões, sabotagens e expressões verbais bem rudes e, iii) finalmente, lutas, ataques físicos, destruição de objetos e propriedade, além de estupro, entre outros atos. O modelo usado por Neuman e Baron (1998) apresenta inúmeros fatores como possíveis causas da agressividade, entre eles: sociais e situacionais, determinantes pessoais e estados internos, que podem levar a interpretações e cognições, as quais, por sua vez, podem levar aos atos agressivos. Para os autores, entretanto, os atos de violência raramente envolvem ataques físicos, já que a tendência é serem simbólicos, verbais e passivos.

Para Weaver (1997), o ponto de vista de que a organização é um lugar de violência controlada, tal como proposto por Foucault (1987), precisa ser contraposto à visão de Dewey, que considera as organizações fóruns edificantes da construção social. O ponto de vista de Weaver (1997) é o de que as duas perspectivas contribuem para o entendimento do espaço organizacional, uma vez que a visão esperançosa de Dewey é um contraponto ao fatalismo foucaultiano. Para Foucault (1987), a disseminação das organizações e da tecnologia espalhou o controle pan-óptico por toda a sociedade. Na visão de Weaver, entretanto, o que a proposta foucaultiana oferece é uma estratégia para lidar com o contexto, mecanismos de luta que podem ser úteis exatamente para o entendimento de um contexto de violência que hoje não é mais tão direta, mas que continua presente em novas formas disciplinares de controle. Além disso, Weaver (1997) argumenta que na visão pragmática de Dewey o progresso é uma forma de atenuar a crueldade tanto física quanto emocional presente no convívio humano, e que o espaço organizacional é o lugar de integração do trabalho, das artes (no sentido também de artes do ofício) e de atividades políticas que podem ser conduzidas num ambiente relativamente democrático. Ainda que essas ideias comportem certa ingenuidade e romantismo, Weaver (1997) argumenta que as corporações são, atualmente, um lugar para interação, para criação do presente e também do futuro.

Bryant e Cox (2003), por sua vez, exploram a questão da violência psicológica entre empregados durante mudanças organizacionais em uma empresa na Austrália. Mais difícil de definir que a violência física, a violência psicológica inclui, por exemplo, isolamento, exclusão das pessoas em processos de decisão, bem como brincadeiras ou jogos realizados durante o trabalho. Os trabalhadores entrevistados mostraram que, ao contrário da racionalidade supostamente exercida pelos gestores e colegas, violência e atrocidades estiveram presentes no processo de mudança, o que levou muitos dos trabalhadores a ter uma atitude de resignação e até a deixar a empresa estudada. Isso reforça a ideia da organização como lugar onde a violência subliminar, e não explícita, está presente.

Também analisando o tema da violência nas organizações, Van Emmerik, Euwema e Bakker (2007) apresentam um estudo quantitativo, realizado com 2.782 trabalhadores e baseado na perspectiva do contrato psicológico de trabalho. Os autores mostram que essa violência leva a uma queda no desempenho profissional, ou seja, à falta de dedicação e de comprometimento, mas que também pode ser amenizada pelo apoio que o empregado receba dos seus pares. 
Há, ainda, autores que relacionam a questão da violência com questões de gênero e sexualidade. Por exemplo, para Flemming (2007), a despeito das organizações serem consideradas esferas dessexualizadas, dominadas pelo discurso da racionalidade, mesmo que vários estudos tenham demonstrado como a sexualidade foi excluída do espaço organizacional (BURRELL, 1984), esta se faz presente nas organizações, em geral, na forma de resistência. Na verdade, o autor discute que a sexualidade nas organizações pode ser vista tanto como resistência quanto como controle, numa combinação dos dois processos. Além disso, ele apresenta um estudo de caso em que mostra que a reerotização também está presente em disputas políticas onde a violência implícita é um elemento a ser considerado. Nesse sentido, é possível discutir que a sexualidade e variadas expressões de gênero estão presentes de forma marcante nos contextos organizacionais e que, de certa forma, podem estar relacionadas a formas de exercício de violência subliminar.

Nessa perspectiva, alguns autores parecem indicar que a questão da violência organizacional pode ser entendida como uma manifestação da masculinidade. Scheff (2003) explora a violência presente nas figuras de liderança, a fim de construir uma teoria sobre as origens da violência masculina. De acordo com o autor, três fatores são essenciais para o aparecimento da violência: a falta de vínculos afetivos, os diferentes tipos de obssessão individual e uma completa repressão do sentimento de vergonha. Scheff (2003) retoma diversos estudos sobre a figura de Hitler, para mostrar que essas três condições estiveram presentes de forma decisiva na vida do ditador. Para o autor, essas condições estão mais presentes nos homens - o que faz da violência uma característica inerente à masculinidade -, ainda que nas mulheres também possam levar a condutas violentas. Se for considerado que o management é uma construção masculina, pode-se levantar a hipótese de que este necessariamente carrega violência na sua estruturação. O estudo de Hearn e Parkin (2001) caminha nessa direção ao mostrar que questões de gênero, sexualidade e violência estão inevitavelmente ligadas à trajetória de construção social das organizações, bem como à vida organizacional contemporânea. Os autores argumentam que as organizações podem ter sua violência manifestada como uma constante ameaça de violação de seus funcionários.

Ainda quanto ao tema organização, masculinidade e violência, apoiado na abordagem de Julia Kristeva, Linstead (1997) mostra que as emoções foram, aparentemente, excluídas das organizações burocráticas. Porém, essa negação não impede que a associação histórica entre racionalidade e masculinidade, componentes da psicologia masculina, esteja presente como dominação nos ambientes organizacionais. De fato, para Linstead (1997), não é possível esquecer que tanto na visão marxista como na weberiana as organizações podem ser entendidas como estruturas de dominação nas quais a violência está institucionalizada nos sistemas de autoridade e comando. No entanto, é necessário compreender como esse processo opera nos indivíduos. Ele emprega a ideia de "dejeção", mostrando que, além da cisão (estudada por M. Klein), da neutralização (estudada por Winnicott) e da negação (estudada por Freud), está presente também o mecanismo de exclusão. Ao aplicar esse conceito para o comportamento masculino (violento) nas organizações, Linstead (1997) mostra que a identidade masculina foi construída ao longo da história por meio de uma dissociação de sensibilidade e sentimentos, que, paradoxalmente, continuam presentes no espaço organizacional. Na sua visão, os homens continuam reproduzindo comportamentos violentos, ainda que não os entendam, e, portanto, as organizações, como lócus primordial da dominação masculina, continuam patriarcais e falocêntricas. Dessa forma, é possível discutir que a violência subliminar em contexto organizacional está associada à masculinidade, conforme acabamos de indicar. Para desenvolver esse argumento, utilizaremos a noção de violência simbólica, foco da próxima seção.

\section{Violência simbólica}

Apesar de consistentes, as diferentes abordagens conceituais utilizadas nas pesquisas anteriormente apresentadas para a compreensão da violência no trabalho não incluem os argumentos de Bourdieu (1999) sobre a dominação masculina e o conceito de violência simbólica. Para Bourdieu (1999), as relações sociais contemporâneas são permeadas pela dominação masculina, que se expressa por uma paradoxal submissão feminina derivada da onipresença da violência masculina, quase invisível e, por vezes, até mesmo suave. Na visão do autor, a construção social dos gêneros foi tão naturalizada que nossa apreensão da divisão entre os 
sexos se dá a partir de esquemas perceptivos inconscientes, incorporados ao longo do processo histórico. Baseado em estudos etnográficos feitos com os berberes de Cabília, o autor mostra que "a força da ordem masculina se evidencia no fato que ela dispensa justificação: a visão androcêntrica impõe-se como neutra e não tem necessidade de se enunciar em discursos que visem legitimá-la" (BOURDIEU, 1999, p.18). A partir da análise das relações entre homens e mulheres desse grupo social, das palavras utilizadas para nominar os órgãos sexuais masculinos e femininos, bem como dos verbos que descrevem o ato sexual, o autor discute as diferenças (inevitáveis de dominação) presentes entre homens e mulheres.

Além disso, Bourdieu (1999) analisa as palavras que designam o ato sexual, em vários idiomas, mostrando que este é um ato de dominação masculina e que suas manifestações estão calcadas na lógica masculina de demonstração de virilidade, grandiosidade e honra. As práticas da sexualidade são assimétricas para ambos os sexos, nos diz Bourdieu, e ainda hoje a lógica amorosa é bastante distinta para os homens e para as mulheres. A sexualidade, para o homem, está ligada ao poder. Nesse sentido, pode-se argumentar que Bourdieu adota a visão psicanalítica freudiana expressa no clássico texto $O$ mal-estar na civilização (Freud, 1997). No entanto, Bourdieu (1999) avança na compreensão de como a aprendizagem dessa lógica se verifica, de modo invisível, por meio da construção social do corpo de meninos e meninas e dos modos de conduta pelos quais a feminilidade consiste em se fazer pequena, num "confinamento simbólico" que sempre confere aos homens um lugar de maior destaque. Os movimentos feministas não romperam essa lógica, e as propagandas contemporâneas são uma evidência desse modelo em ação ainda hoje, afirma Bourdieu (1999, p.40). Nessa visão, a intuição feminina, assim como a de outros grupos dominados, seria a forma como a mulher consegue antecipar desejos de modo a contentar o dominador, que se impõe com seu poder, poder este exercido física ou simbolicamente. Trata-se de uma forma de sobrevivência que, ao mesmo tempo, legitima a visão androcêntrica do mundo.

A dominação masculina se exerce, portanto, em estruturas sociais, no exercício do habitus, em microatividades, na linguagem, de modo sutil, tanto nas atividades de trabalho como nas relações de reprodução. Tal dominação estaria calcada na ameaça da possibilidade do exercício da violência. Ou seja, a dominação está calcada na presença de uma violência sutil, quase imperceptível, que se manifesta, assim, como constante ameaça. A matriz androcêntrica está presente na forma de perceber, de pensar e de agir das práticas cotidianas, vistas como senso comum, pois já incorporaram as relações de poder e de dominação.

Ao tratar da violência simbólica, entretanto, o autor não esconde a violência física que também pode estar presente; ou melhor, que pode ser empregada. Além disso, a violência simbólica tem efeitos práticos e reais em relações de dominação e submissão expressas no cotidiano, quase invisíveis, exatamente, por sua naturalização na ordem social. Para Bourdieu (1999), dominação masculina e violência simbólica são sinônimos, o que significa dizer também que o dominado assume o ponto de vista do dominador, reconhecido como natural. Após elaborar brevemente algumas noções que serão importantes para a análise dos dados presentes neste artigo, na próxima seção apresento a abordagem metodológica nele empregada.

\section{Abordagem metodológica}

\section{Etnografia e análise das organizações: o etnógrafo em ação}

Os dados que originaram este artigo foram coletados por meio de uma abordagem etnográfica. Apesar de todas as dificuldades associadas com a proposição de uma definição geral do que é etnografia, é possível argumentar que ela geralmente envolve:

o etnógrafo participando, aberta ou reservadamente, na atividade de um dado grupo por um extenso período de tempo, observando o que acontece, escutando o que é dito, fazendo perguntas - de fato, coletando todo tipo de dado disponível para iluminar assuntos e eventos que estão no foco de sua pesquisa. (HAMMERSLEY; ATKINSON, 1995, p.1) 
Um envolvimento intenso no trabalho de campo (AGAR, 1980) pode ser visto como uma das suas características distintivas. Dessa forma, ela está enraizada na experiência de "primeira mão" no local pesquisado e está comprometida com a compreensão do ponto de vista daqueles que estão sendo pesquisados (ATKINSON et al, 2001). Assim, a etnografia "levanta dados empíricos sobre a vida de pessoas e situações específicas" (SPRADLEY, 1979, p.13).

Apesar de ser o método da antropologia por excelência, sua influência vai muito além dessa disciplina, em pesquisas nos campos mais diversos como a medicina e os estudos organizacionais. Tal abordagem vem sendo vital para desenvolver uma compreensão aprofundada do mundo da administração, das organizações e do trabalho. Uma de suas principais contribuições é coletar dados extremamente ricos a respeito dos ambientes organizacionais analisados. Para Van Maanen (1979, p.540), a etnografia organizacional tende a "revelar e explicitar as formas e maneiras como as pessoas que trabalham em locais particulares vêm a entender, explicar, tomar ações e gerir suas situações cotidianas".

Os dados para este artigo foram coletados de meados de setembro de 2005 até o final de junho de 2006. Durante esse período, o autor acompanhou as atividades cotidianas de uma gráfica de jornais. Por quase nove meses, o pesquisador observou diariamente as atividades nessa organização. Ele foi à empresa durante todas as semanas desses meses - tipicamente, cinco dias por semana -, permanecendo ali de 8 a 12 horas por dia. Como a empresa trabalha em turnos diurnos e noturnos, o pesquisador procurou observar atividades em ambos. Após o término de cada dia de observação, o pesquisador redigiu diários de campo, de acordo com a prática corrente dos etnógrafos (v. SANJEK, 1990), em que relatava os principais eventos que observou na gráfica. No total, o pesquisador produziu pouco mais de 2 mil páginas de diários de campo. Após o período de campo, ele codificou os dados por meio da leitura exaustiva dos diários, a fim de encontrar temas e temáticas, tanto teóricas quanto empíricas, recorrentes. Além disso, o autor tirou mais de 2.500 fotografias, coletou cerca de $1 \mathrm{~GB}$ de documentos e um total de 63 desenhos realizados por funcionários da gráfica. Neste artigo, serão tratados somente os 53 desenhos realizados pelos operários, muito embora as demais informações sirvam como pano de fundo para a análise e os argumentos aqui desenvolvidos. É importante destacar que, durante o período de campo, o pesquisador observou atividades tanto no chão de fábrica quanto nos escritórios dos executivos, e que o foco principal foram as atividades relacionadas com a produção de jornais. Antes de detalhar como e por que os desenhos foram coletados, realizo uma breve descrição e contextualização da gráfica.

\section{A empresa e o contexto}

A empresa analisada neste artigo é uma das maiores gráficas de jornais da Europa, e de agora em diante será denominada Press, para preservar seu anonimato. Localizada no norte da Inglaterra, nela são impressos semanalmente mais de 35 diferentes jornais, inclusive, diários de circulação em todo o Reino Unido, sejam tabloides ou jornais considerados localmente como "sérios". A Press imprime mais de 15 milhões de exemplares por semana, contando com nove rotativas que funcionam praticamente 24 horas por dia. Quando da elaboração do estudo aqui apresentado, a Press tinha 290 empregados, dos quais 106 trabalhavam exclusivamente nas rotativas, um dos principais focos deste estudo. É importante salientar que a gráfica faz parte de um dos maiores grupos de mídia no mundo. Somente no Reino Unido, o grupo possui mais de 500 diferentes marcas de produtos relacionados à informação, cerca de 240 jornais locais e regionais e cinco jornais nacionais, empregando mais de 10 mil pessoas. $\mathrm{O}$ faturamento anual é de cerca de $\mathrm{R} \$ 3,4$ bilhões.

Antes de prosseguir com a descrição dos eventos que estavam acontecendo na Press, o que auxiliará a contextualizar os elementos discutidos neste artigo, é importante salientar que a indústria de jornais enfrenta atualmente a maior crise de sua história. "Quem matou os jornais?" foi a irônica e contundente manchete de capa do influente semanário The Economist no dia 24 de agosto de 2006. A matéria da revista explicita os significativos problemas enfrentados recentemente por essa indústria. Segundo a reportagem, o ano de 2005 fora um dos piores da história para os jornais, principalmente, nos países desenvolvidos. A estimativa é de que até 2015/2016, 25\% dos anunciantes venham a trocar os jornais impressos pela mídia digital (THE ECONOMIST, 2006). Nos EUA, em 1964, quase 81\% dos adultos liam um jornal diariamente. Em 2004, somente 52,8\% ainda o faziam. Na França, entre 1972 e 2001, as vendas do produto caíram 40\%. No Reino 
Unido, entre 1999 e 2002, os jornais perderam cerca de 5 milhões de leitores (THE ECONOMIST, 1999). Títulos tradicionais como Le Monde, The Guardian e The New York Times estão atingindo as menores circulações diárias de sua história. Até mesmo os tabloides ingleses, conhecidos por serem campeões de vendas, enfrentam graves problemas. Por exemplo, em 1964 o Mirror possuía uma circulação diária de pouco mais de 5 milhões de exemplares. No ano 2006 a circulação média do tabloide foi de pouco mais de 1,5 milhão de exemplares por dia .Isto é, a leitura dos jornais se reduz dramaticamente, ao mesmo tempo em que os anunciantes estão migrando para formas mídias mais modernas. Nesse contexto, há aqueles que ousam, inclusive, sentenciar quando o último jornal da história dos EUA será impresso (v. MEYER, 2001). Segundo os executivos da Press, no melhor dos cenários, a gráfica teria 33\% menos demanda em cinco anos. Nesse contexto de mercado é que as observações etnográficas desta pesquisa foram realizadas.

Nesse cenário de indústria em declínio, a Press estava sob a ameaça de ser fechada. Segundo o próprio diretorgeral da empresa, se a gráfica não conseguisse atrair investimentos para a modernização de seu parque tecnológico, seria fechada dentro de alguns anos; isso porque as rotativas têm vida útil de aproximadamente 15 anos, e as nove máquinas existentes na Press já estavam em operação há cerca de 17 anos. Portanto, eram consideradas não apenas tecnologicamente ultrapassadas, mas também muito caras, devido aos elevados custos de manutenção, para continuarem em funcionamento. Para agravar a situação, em seus planos de investimentos para os próximos anos, o grupo proprietário da Press já havia decidido não investir na modernização da gráfica devido a fatores relacionados à sua localização, pois já possuía cinco gráficas de jornais espalhadas pelo Reino Unido. Porém, a questão geográfica, que num primeiro momento parecia problemática, acabou posteriormente auxiliando, uma vez que, para tentar atrair mais receitas, a Press estava realizando trabalhos para empresas de fora do grupo a que pertencia. Um dos principais clientes que terceirizavam trabalhos para a Press era um dos jornais tidos como de qualidade e com maior penetração no país. Esse jornal enfrentava dificuldades para modernizar seu próprio parque tecnológico, localizado na mesma região onde estava a Press. Após várias tentativas e intensas negociações, fora decidido que a melhor estratégia seria juntar esforços com a Press e adquirir novos equipamentos em conjunto. Dessa forma, em parceria com um de seus clientes, a Press trocou quatro de suas nove rotativas, num investimento equivalente a mais de $\mathrm{R} \$ 160$ milhões. Isso foi possível porque, quando o grupo proprietário da Press recebeu a oferta de investimento compartilhado, seus executivos consideraram que essa seria uma forma de modernizar o próprio parque gráfico a um custo bastante reduzido, alterando então seu plano de investimento. No novo plano, a Press aparecia como um dos parques gráficos que teria "futuro".

Em um primeiro momento, a notícia de que a Press receberia investimentos em novo maquinário gerou bastante euforia, pois se acreditava que o futuro da gráfica estaria garantido; ao menos, até as novas máquinas ficarem obsoletas, o que levaria no mínimo uns 15 anos. Todavia, novas rotativas requerem menos funcionários para operar e representam uma tecnologia totalmente nova que demanda novas formas de trabalho. Ou seja, não só as novas rotativas demandariam menos operadores, como também iriam requerer dos trabalhadores novas habilidades para funcionar com eficiência e eficácia. Nesse contexto, os executivos da Press decidiram que as novas rotativas teriam funcionários dedicados apenas a elas. Para decidir quem seriam tais funcionários, foi realizado um processo seletivo entre os operadores de rotativas. Desse modo, todos os interessados em trabalhar nas novas máquinas deveriam enviar um currículo atualizado e passar por entrevistas. Concluído esse processo, os selecionados foram treinados intensivamente para operar as novas máquinas. Além disso, pelo fato das novas rotativas demandaram menos mão de obra, foi aberto um processo de demissão voluntária pelo qual 65 operadores deveriam deixar a organização. Caso não fossem encontrados voluntários suficientes, a Press faria uma seleção entre os remanescentes.

A seleção de operários para as novas rotativas afetou as relações no chão de fábrica. Muitos dos preteridos consideravam o processo seletivo injusto, pois os gerentes teriam manipulado o processo com o objetivo de escolher quem previamente queriam. Informalmente, acreditava-se que os operadores das máquinas antigas corriam muito mais risco de serem demitidos e que, em breve, essas máquinas seriam desativadas. Isto é, os operadores do velho equipamento eram percebidos como os que primeiro perderiam suas posições. Além disso, com o passar do tempo, os operadores das novas rotativas perceberam que teriam de trabalhar muito mais do que nas máquinas antigas, que estavam recebendo bem menos (pois tinham menos oportunidades de fazer horas 
extras) e que as novas rotativas, por serem ultramodernas, não requeriam tantos funcionários como fora anunciado. A sensação era a de que as pessoas em ambas as rotativas estavam com problemas.

Após essa breve apresentação do contexto da empresa em foco, a seguir, exploro a maneira como os desenhos foram coletados.

\section{Coleta de desenhos no chão de fábrica}

Logo após o início da pesquisa etnográfica na Press, ainda não estava bem definida a forma como o pesquisador forneceria feedback para a empresa a respeito de seu trabalho. Em um dado momento, o gerente de recursos humanos propôs ao pesquisador que este elaborasse uma pesquisa de clima organizacional, cujos resultados seriam apresentados à empresa. Por achar a ideia de pesquisa de clima um tanto quanto problemática e, também, por imaginar que realizar um estudo como esse poderia sinalizar para as pessoas da empresa que o pesquisador, na verdade, trabalhava para a organização, este começou a pensar em alternativas.

Alguns dias depois, caminhando pelo chão de fábrica, o pesquisador deparou-se com o seguinte desenho:

\section{Figura 1 - Imagem do chão de fábrica}

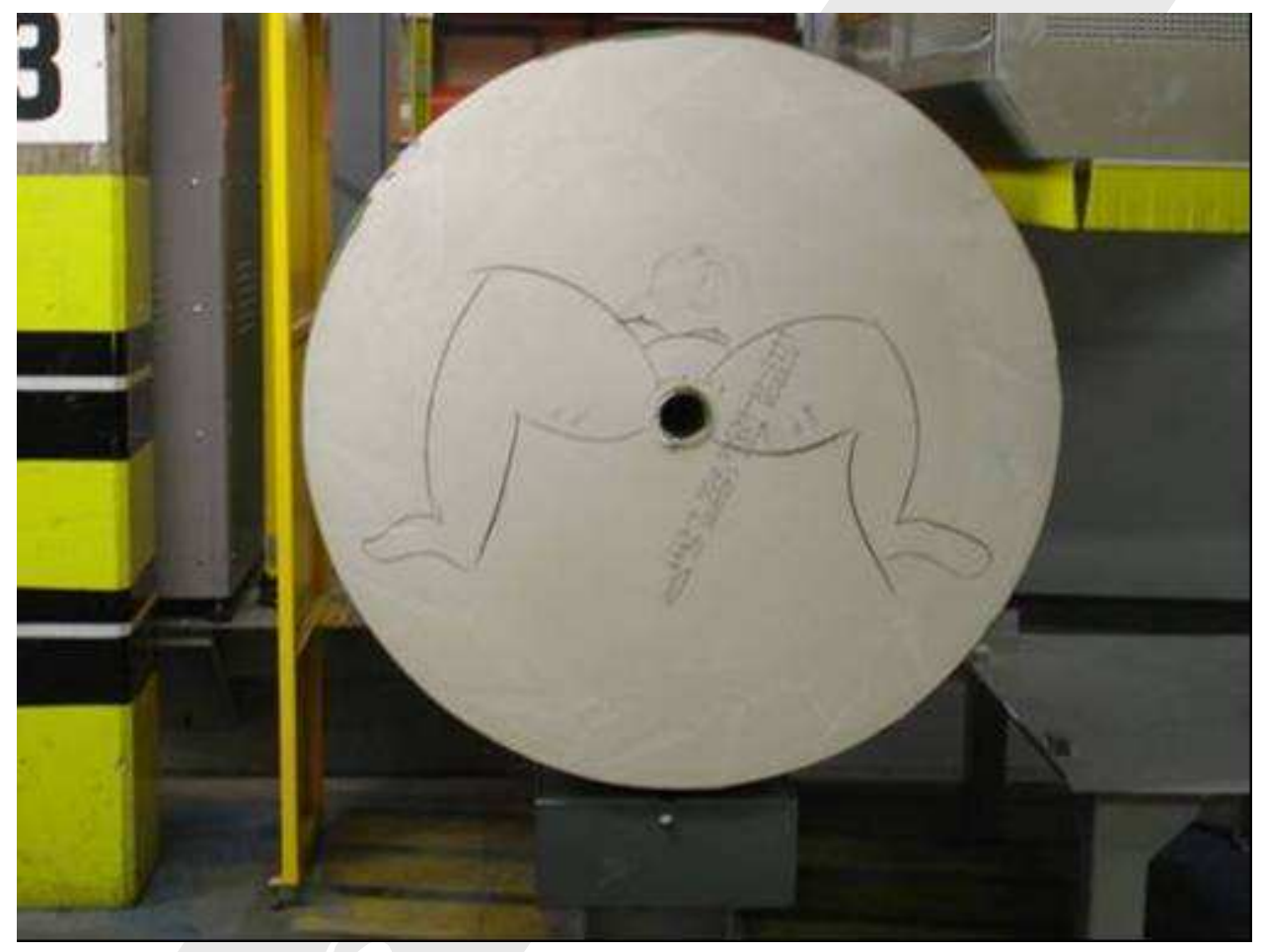

Fonte: tirada pelo pesquisador Rafael Alcadipani

O desenho foi feito por um desconhecido em um rolo de papel que seria utilizado para imprimir jornais na rotativa nova. O pesquisador procurou descobrir quem realizara o desenho para tentar encontrar uma descrição do próprio autor, mas não conseguiu. Ao perguntar para outros operadores o que aquilo significaria, todos disseram que era uma forma de passar o tempo e fazer piada. No caso específico dessa figura 1, trata-se de uma imagem de mulher, com os genitais expostos, que mistura sexualidade com poder e dominação da mulher. A imagem é forte, agressiva e sugere a submissão feminina em face do poder masculino, numa visão androcêntrica. Segundo Bourdieu (1999), é possível argumentar que a imagem representa uma conduta que permeia a ordem social estabelecida na Press (e nas sociedades contemporâneas). Como a imagem estava em local próximo da enfermaria, o pesquisador conversou com a enfermeira-chefe da fábrica, com quem ele tinha proximidade. Muito revoltada, ela disse ver no desenho a prova de que as pessoas da gráfica seriam verdadeiros "gorilas", revelando que em ocasiões específicas, já fora ameaçada por ter negado folga a operários que 
estariam, na sua visão, forjando doenças para não trabalhar. / Muito revoltada, ela disse ver no desenho a prova de que as pessoas da gráfica seriam verdadeiros "gorilas", revelando que já fora ameaçada por negar folgas para operários que estariam, na sua visão, forjando doenças para não trabalhar. Nesse contexto, a imagem pode representar a existência de uma constante ameaça de violação nas organizações (cf. HEARN; PARKIN, 2001), na medida em que mostra uma mulher prestes a ser violentada.

Além disso, o pesquisador se deu conta de que os trabalhadores usavam imagens como brincadeira e para trocarem mensagens entre si, além de, fundamentalmente, recorrerem a esses desenhos para retratar fatos de seu cotidiano. Com isso em mente, decidiu que, em vez de uma pesquisa de clima, seria interessante solicitar aos funcionários da empresa que fizessem um desenho que, no ponto de vista deles, representasse a organização. A ideia foi aprovada pelo gerente de recursos humanos e o pesquisador, então, começou a coletar os desenhos.

Metodologicamente, o pesquisador pensou que conseguir os desenhos dos operários seria uma maneira de coletar informações sobre a organização pesquisada e de seguir o conselho de Hammersley e Atkinson (1995), segundo os quais o etnógrafo deve recorrer a todos os métodos disponíveis para compreender a realidade organizacional. Além disso, no caso específico desta pesquisa, o fato de estar realizando uma etnografia pareceu-lhe uma vantagem, pois conheceria, em detalhes e de forma aprofundada, o contexto em que os desenhos tinham sido feitos, o que nem sempre é o caso quando estes são feitos após entrevistas ou discussões em grupo realizadas sem que o pesquisador tenha conhecimento do dia a dia da organização estudada.

Para a coleta de imagens, o pesquisador abordava os funcionários da Press, deixando com eles uma folha de papel em branco para que fizessem seus desenhos. As pessoas eram informadas de que estes seriam utilizados, sem identificação da autoria, em apresentações genéricas e em artigos acadêmicos dentro e fora da empresa. A todas era solicitado que explicassem o significado de seu desenho. Em geral, quem não tinha dificuldades para desenhar realizou a tarefa sem grandes questionamentos. Aqui, foi fundamental o apoio de alguns informanteschave que, após concluírem seus desenhos, encorajavam os demais a participar. Além disso, o fato do pesquisador estar diariamente no chão de fábrica e com os executivos parece ter dado mais credibilidade à sua ação, já que as pessoas desenhavam sem grande desconfiança. Não era incomum que um funcionário mostrasse seu desenho a um colega e pedisse sua opinião. Nessas ocasiões, havia conversas sobre a adequação (ou não) do que fora desenhado, invariavelmente, rodeadas de piadas. Cabe observar que, por questões de foco da pesquisa, foram solicitados desenhos apenas aos executivos e aos operários das rotativas.

Para efeito deste artigo, falarei apenas dos desenhos dos operadores das rotativas, grupo no qual foram coletadas 53 ilustrações, posteriormente, analisadas. É fundamental frisar que nas rotativas da Press, praticamente, só trabalham homens (há apenas uma mulher), quase todos, ingleses brancos, cuja média de idade é de 43 anos. Além disso, o fato de que os desenhos poderiam ser mostrados aos executivos da empresa pareceu, na opinião do pesquisador, ter criado nos trabalhadores uma expectativa de que dessa vez teriam voz, algo bastante incomum na Press. Com frequência, quem fazia um desenho perguntava ao colega que reação ele achava que os executivos teriam ao ver aquilo. De certo modo, é possível argumentar que os desenhos foram feitos com o intuito de "reagir" às ações dos executivos que estavam alterando o dia a dia da gráfica. Antes de explorar os desenhos em si, farei uma breve contextualização sobre sua utilização como método para compreender as relações de trabalho.

\section{O uso do desenho como técnica de coleta de dados}

É importante frisar que, ainda que a utilização de técnicas projetivas seja comum no campo da psicologia há praticamente um século, a adoção desse procedimento na análise de processos organizacionais é recente. Nas duas últimas décadas, a utilização de desenhos cresceu um pouco - como é possível verificar pelos trabalhos de, entre outros, Buchanan (2001), Dougherty e Kunda (1990), Kunter e Bell (2006), Strangleman (2004), Symon e Cassell (1998) e de Zuboff (1988) -, embora ainda seja incipiente. Esse crescimento decorre das inúmeras críticas feitas aos procedimentos tradicionais em pesquisas qualitativas, como, por exemplo, ao uso recorrente de entrevistas. De fato, ainda que o uso de a realização de entrevistas seja hoje um procedimento de coleta de dados difundido em várias áreas do conhecimento em administração, muitos autores argumentam que a dinâmica presente nos fenômenos organizacionais não é tão facilmente percebida quando se lança mão dessa 
técnica, considerada muito formal (CASSELL; SYMON, 1997). Além disso, a fala expressa nas entrevistas pode muito bem ser controlada pelos sujeitos para o gerenciamento de impressões, enquanto os desenhos podem ser feitos mais livremente, estando, dessa forma, mais próximos da realidade em observação. Outro argumento utilizado é que, mesmo em pesquisas qualitativas, o sentido atribuído pelas pessoas às suas experiências na organização fica quase esquecido (CALDAS; TONELLI, 2002; VERGARA; SILVA, 2000; WOOD JR.; CALDAS, 2005) e que o desenho é uma técnica que pode recuperar esse sentido, livre das limitações impostas pela racionalidade. Meyer (2001), num artigo que é referência nessa área, argumenta que a utilização de técnicas projetivas é um procedimento vantajoso em relação às técnicas tradicionais, uma vez que os desenhos permitem uma comunicação multidimensional com o campo de pesquisa (e não apenas unidimensional, como a fala, na entrevista), além de ultrapassarem a racionalidade e expressarem mais claramente as emoções. $\mathrm{O}$ autor mostra que o uso de diagramas, gráficos de computadores, pinturas e outras representações visuais podem ser muito úteis na pesquisa organizacional. Em síntese, entendemos que a abordagem metodológica deste estudo, que reuniu os desenhos coletados durante a etnografia, permitiu uma grande aproximação da realidade dos trabalhadores da Press, assim como uma melhor avaliação de aspectos subliminares presentes no contexto dessa empresa.

\section{Masculinidade e violência na Press}

A análise preliminar dos desenhos levou, em primeiro lugar, à questão da hostilidade e da agressividade, às vezes mais sutil, às vezes mais declarada, mas sempre presente na realidade organizacional da Press. De fato, essa manifestação foi tão forte que nos motivou a buscar a revisão da literatura sobre a violência nas organizações, que já apresentamos anteriormente neste artigo. Não partiu-se da violência; a violência estava lá, presente, simbólica, não só nos desenhos, mas perpassando todas as relações de trabalho que pude observar. A análise desses 53 desenhos permitiu construir três categorias de interpretação, a partir do conceito central de violência que pareceu oportuno, para dar significado aos desenhos coletados. A violência apareceu associada com: i) sexualidade (cf. HEARN, 1994; HEARN; PARKIN, 2001), ii) opressão (NEUMAN; BARON, 1998) e também com iii) autodestruição (cf. BRYANT; COX, 2003). Apresento a seguir essas três categorias, com exemplos de imagens que marcam a interpretação. Não é possível, por questão de espaço, apresentar aqui todos os desenhos coletados. É importante salientar que, devido à agressividade presente nos desenhos, ficou decidido que eles não deveriam ser apresentados para os executivos da empresa, uma vez que poderiam acirrar ainda mais as já conturbadas relações industriais na Press.

\section{Violência e sexualidade}

A ideia de que o management carrega necessariamente questões de gênero, sexualidade e violência (HEARN; PARKIN, 2001) está claramente presente na realidade organizacional da Press. As duas imagens apresentadas a seguir mostram visivelmente essa interseção. Na figura 2, a própria organização, como lugar, é definida pela expressão " $f *$ *king airport" cheio de "arseholes". A relação com a sexualidade é evidente. 


\section{Figura 2 - A Press como um "aeroporto" de "arseholes"}

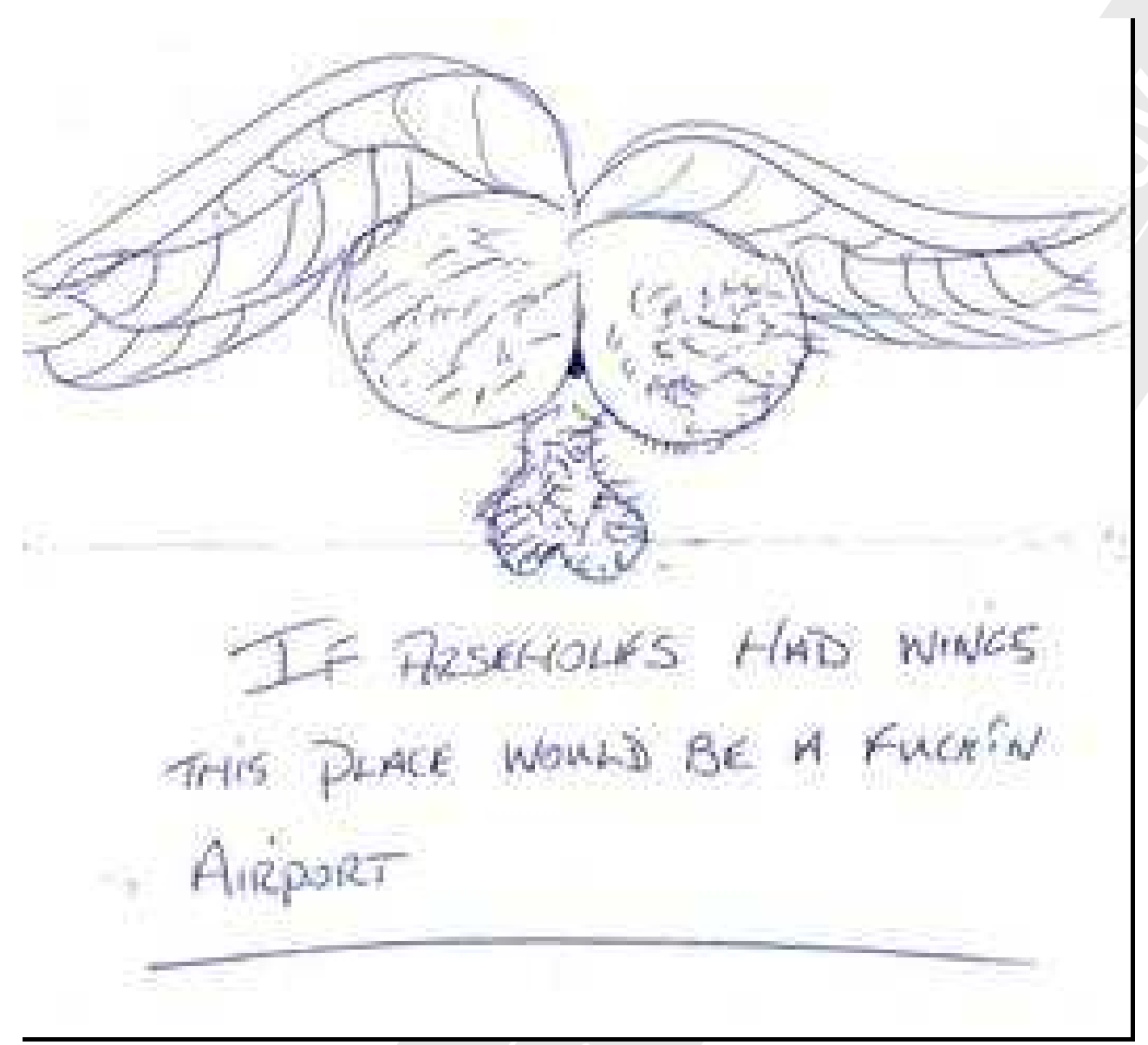

Fonte: Desenho feito por funcionário. Por questões éticas, o nome do autor deve ser preservado.

O operador que fez esse desenho disse ao pesquisador que essa é a melhor forma de expressar a empresa, principalmente, os gestores, os quais, segundo ele, são todos mal-intencionados na maioria das suas ações. No seu ponto de vista, os próprios companheiros de trabalho tentavam prejudicar uns aos outros. Quando ele mostrou a imagem para alguns companheiros, todos deram gargalhadas, dizendo que ele estava certíssimo na sua representação da Press e de seus gestores. Dessa forma, a violência dirigida contra os gestores também é evidente. Segundo Listead (1997), as organizações são locais em que a violência masculina se expressa, e a figura 2 pode ser ententida como uma forma de representar uma tentativa de subverter a sexualidade dos que exercem a violência, na medida em que aparecem representados como "arseholes".

Outra imagem representativa da ligação entre violência e sexualidade pode ser vista na figura 3 , onde os gestores são representados como dickheads. 
Figura 3 - Os gestores são apresentados como dickheads

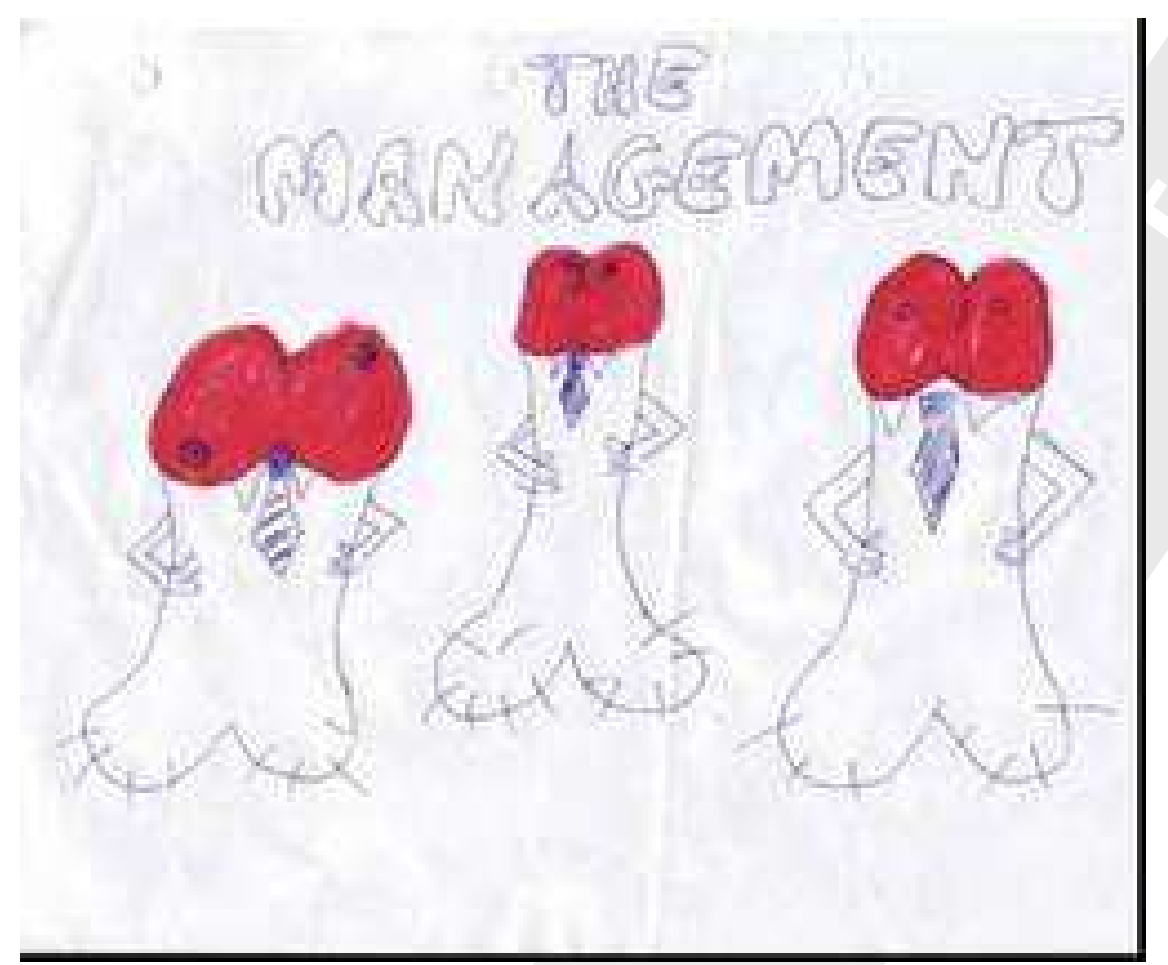

Fonte: Desenho feito por funcionário. Por questões éticas, o nome do autor deve ser preservado.

Nessa figura, os dirigentes são retratados por órgãos sexuais masculinos de gravata, indicando que eles seriam "estúpidos", nas palavras do operador que fez o desenho. Segundo ele, isso mostraria que a Press é caracterizada fundamentalmente por gestores que não levam em consideração os funcionários, que agem de maneira agressiva e, acima de tudo, são "estúpidos". Esse fato se relaciona com o comportamento masculino agressivo presente nas figuras de liderança e poder, conforme abordado por Scheff (2003). A imagem também pode indicar a presença dos gestores como provável fonte de possível violação (cf. HEARN; PARKIN, 2001) dos funcionários, ao mesmo tempo em que a imagem anterior pode induzir a presença da figura que pode ser violada (por exemplo, os flying asses).

Em ambas as representações, dirigentes e trabalhadores são mostrados como um coletivo marcado pela sexualidade e pela conduta agressiva (cf. BOURDIEU, 1999). No entanto, além das pessoas, também a organização, como um todo, é representada claramente pelos valores masculinos, carregada de uma sexualidade nitidamente agressiva, indicando de forma subjacente que a organização é assim. Conforme afirma Bourdieu (1999), a sexualidade masculina é agressiva e permeia a organização social. Em outras palavras, pode-se especular que não só a Press, mas todas as organizações podem ser entendidas dessa forma, expressa em microatividades permeadas pela violência simbólica no cotidiano das relações de trabalho. Para Flemming (2007), representações da sexualidade podem estar presentes nas organizações na inter-relação entre resistência e controle. No caso dos dois desenhos anteriormente apresentados, a sexualidade aparece como uma forma de expressar resistência contra a opressão da organização, resistência essa praticada pela elaboração dos desenhos apresentados nesta seção.

A seguir, discutirei outra categoria utilizada para analisar os desenhos feitos pelos operários das rotativas da Press.

\section{Violência e opressão}

A violência está associada com a opressão conduzida pelos dirigentes. Conforme afirma Linstead (1997), sempre é necessário lembrar a perspectiva de Weber e Marx: as organizações são sistemas de dominação, e a 
violência está institucionalizada nas posições de comando, conduzidas por sistemas de autoridade formais, legitimados, de controle. A figura 4 mostra o tamanho evidentemente superior dos dois novos gestores - vistos como pessoas que praticam bullying como forma de violência contra os operadores da Press -, que estão sendo apresentados aos trabalhadores. Aqui, é interessante destacar que o assédio moral é uma forma de violência subliminar presente no cotidiano das organizações (FREITAS, 2008). Os gestores apresentados na figura são grandes, fortes, têm uma expressão marcadamente agressiva, e estão lá, evidentemente, para exercer o domínio sobre os demais, representados como figuras menores. São figuras tipicamente masculinas. Segundo Bourdieu (1999), a violência simbólica é exercida pela imposição da potência masculina, representada, na próxima figura, pela força física. $\mathrm{O}$ autor destaca ainda que tal violência pode se expressar pela construção simbólica dos corpos masculinos, claramente presente na figura destacada. A indicação do bullying sugere que a violência é velada, escondida. O contexto desse desenho está relacionado com o fato de que, após a implementação da nova rotativa, ficou decidido que as máquinas novas e velhas teriam, cada uma delas, um gerente dedicado. A figura 4 indica que, na percepção de alguns dos operadores da fábrica, tais gerentes seriam mais duas pessoas que estariam lá para oprimir os empregados da Press, de acordo com o autor do desenho. Ao colocar a palavra "bullying" na camiseta dos pseudogestores, o desenho parece representar a figura do macho como autor da violência simbólica, conforme destacado por Bourdieu (1999).

Figura 4 - Os novos gerentes de área da Press

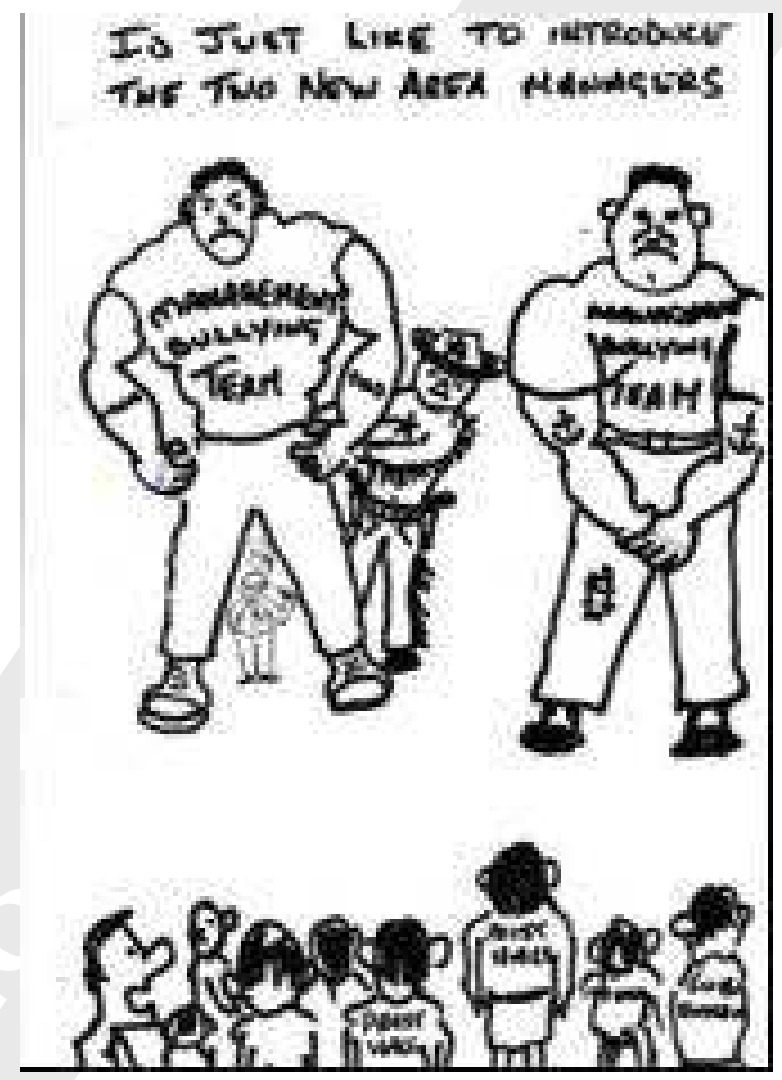

Fonte: Desenho feito por funcionário. Por questões éticas, o nome do autor deve ser preservado.

$\mathrm{Na}$ figura 4, ao fundo, aparece também uma pessoa vestida como um xerife. Trata-se de uma alusão ao gerente de produção da empresa, o qual, quando assumiu seu posto, disse que os operários deveriam começar a "tomar jeito", pois havia um "novo xerife na cidade": nada mais masculino. $\mathrm{O}$ autor do desenho acrescentou que como o xerife não conseguiu exercer seu poder no chão de fábrica, teve de criar o cargo para dois assistentes, que teriam de ser ainda mais agressivos. O interessante nesse aspecto é o reforço da relação entre masculinidade e 
dominação utilizando-se um arquétipo tipicamente masculino como o xerife, que detém, em teoria, o monopólio da violência, como um ator a exercer a violência simbólica (cf. BORDIEU, 1999). Segundo Bourdieu (1999), a matriz androcêntrica é a fonte da violência simbólica, e a figura em questão mostra tal matriz de forma clara e em ação. Um último ponto a ser destacado na figura 4 é o fato de que os gerentes aparecem como claramente masculinos, ao passo que o gênero dos operários é bem menos evidente. Estes parecem desprovidos de masculinidade.

A figura 5, por sua vez, retrata os gestores como "nazistas" que dividiram o chão de fábrica entre operadores de rotativas novas e velhas, ao mesmo tempo em que reduziam os salários desses funcionários. O nazismo, como regime opressor, também, esteve fundamentado em uma matriz androcêntrica que prosperou em uma figura de liderança masculina. Aqui, o fato de a liderança ser apontada como nazista acaba por relacionar violência, liderança e masculinidade, a exemplo de Scheff (2003). Na visão de quem fez o desenho, os que trabalhavam nas rotativas velhas sentiam-se totalmente inseguros, enquanto aqueles que operavam as novas estariam felizes por terem seu emprego garantido, / estariam felizes, supondo que seu emprego estivesse garantido, tendo sido instaurado um regime do terror em que as violações são uma constante ameaça (cf. HEARN; PARKIN, 2001).

Newman e Baron (1998) observam que a opressão é uma das várias formas pelas quais a violência pode se manifestar nas organizações. Na figura a seguir, a opressão como forma de violência que instala até mesmo uma "cortina de ferro", e que faz com que alguns tenham satisfação enquanto outros são inferiorizados, está claramente presente. Além disso, essa imagem pode ser encarada como a expressão da violência em contextos organizacionais sob mudança, conforme analisado por Bryant e Cox (2003).

Figura 5 - Os gestores nazistas e a fábrica dividida

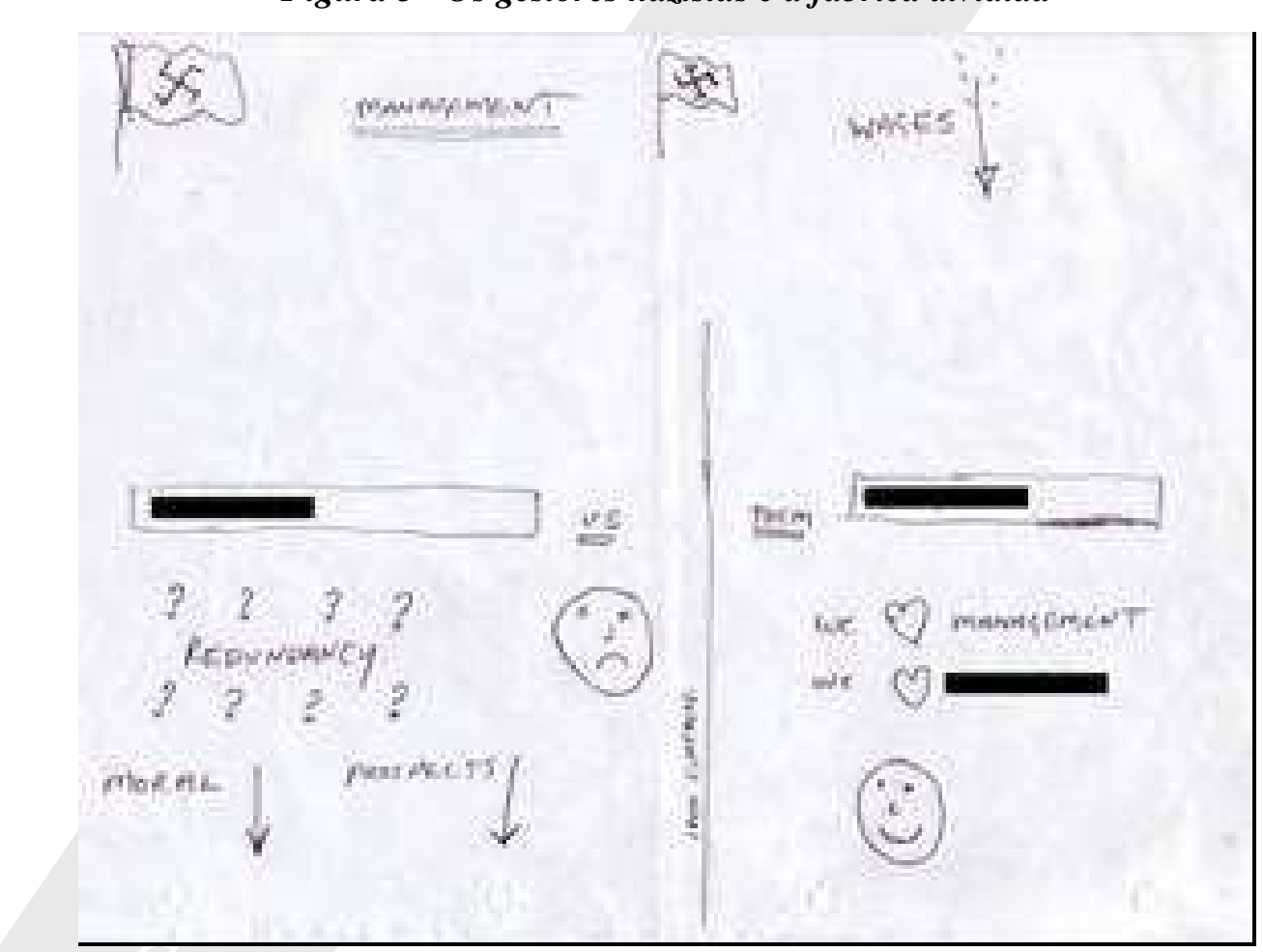

Fonte: Desenho feito por funcionário. Por questões éticas, o nome do autor deve ser preservado.

Ambas as figuras mostram o chão de fábrica como um lugar opressivo; sendo tal opressão garantida pela força, como no caso da figura 4, e pelo terror, como mostra a figura 5. Nos dois casos, a masculinidade perpassa essa relação de poder como uma ameaça de violação dos funcionários (cf. HEARN, 1994; HEARN; PARKIN, 2001); um domínio que ao ser exercido se revestiria de um caráter masculino. Nesse sentido, é importante salientar que ambos os desenhos entram no nível da representação simbólica da violência percebida nas relações entre gestores e operadores da gráfica, uma vez que reações de agressividade "de fato" nunca tenham 
sido testemunhadas pelo pesquisador. Desse modo, a opressão aqui descrita está associada à violência simbólica, pois é expressa de forma subliminar nas diferentes ações dos gestores, nas diferentes práticas associadas com a masculinidade (cf. BOURDIEU, 1999). No caso desses dois desenhos anteriormente apresentados, é possível sugerir que muitos dos operários perceberam a cisão do chão de fábrica entre rotativas novas e velhas como um ato de agressividade, como uma forma de violência simbólica, como a imposição da potência masculina dos gestores.

\section{Violência e autodestruição}

As figuras 6 e 7 expressam os efeitos da violência contra os trabalhadores, que leva a uma autodestruição simbólica. A figura 6 mostra o enjoo, o adoecimento, bem como a solidão do indivíduo em face do seu cotidiano de trabalho. Ao fazer o desenho, o funcionário afirmou que só conseguia se sentir "enjoado", no sentido fisiológico, quando acordava e tinha de ir trabalhar na Press. Segundo ele, o trabalho é desgastante e os gerentes não se importam com que os operários fazem no chão de fábrica. Estes jamais seriam considerados quando as decisões são tomadas, sentindo-se constantemente sufocados pelo regime vigente na gráfica. Esse mesmo funcionário comentou que o dia a dia na Press lhe faz mal, está "acabando" com a sua vida e que, ao longo dos anos, o trabalho minou sua autoimagem, o que indica uma dominação subliminar (cf. BOURDIEU, 1999) e destruidora no cotidiano das relações de trabalho naquela empresa.

\section{Figura 6 - Operário cansado}

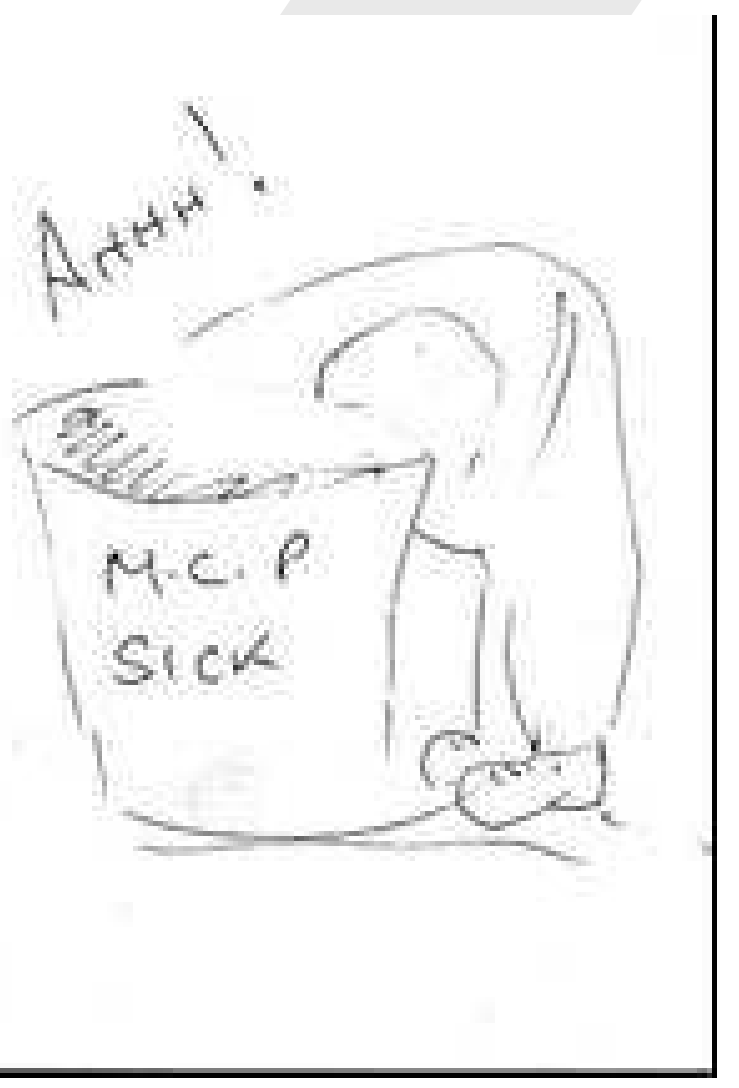

Fonte: Desenho feito por funcionário. Por questões éticas, o nome do autor deve ser preservado.

Na figura 7, como última alternativa, a morte, expressa no desenho da forca, onde o rosto do enforcado está visivelmente triste. Esse desenho foi feito por um operador da nova máquina, o qual dizia que, ao ter mudado para a nova máquina, cometera suicídio, pois ganhava menos e tinha de trabalhar muito mais. De acordo com ele, na nova máquina, os operadores estão submetidos a pressões muito maiores e, também, a sanções disciplinares muito mais severas do que na rotativa velha. Quando esse desenho foi feito, um grupo de 
operários da nova rotativa tinha recebido uma repreensão por escrito devido a um erro cometido. Na rotativa velha, situação semelhante não daria margem a tal repreensão. / Em situação semelhante na rotativa velha, a disciplina não seria aplicada dessa forma. Nas duas figuras, a violação não se apresenta como uma ameaça (cf. HEARN; PARKIN, 2001), mas como um ato consumado em que o enjoo e a morte estão consubstanciados. Essas imagens sugerem que os operários estão sendo vitimados por um processo de mudança (cf. BRYANT; COX, 2003 da velha para a nova tecnologia. Aqui, a potência masculina (cf. BOURDIEU, 1999) parece ter consumado seu ato de arbitrariedade.

Figura 7 - Operador enforcado

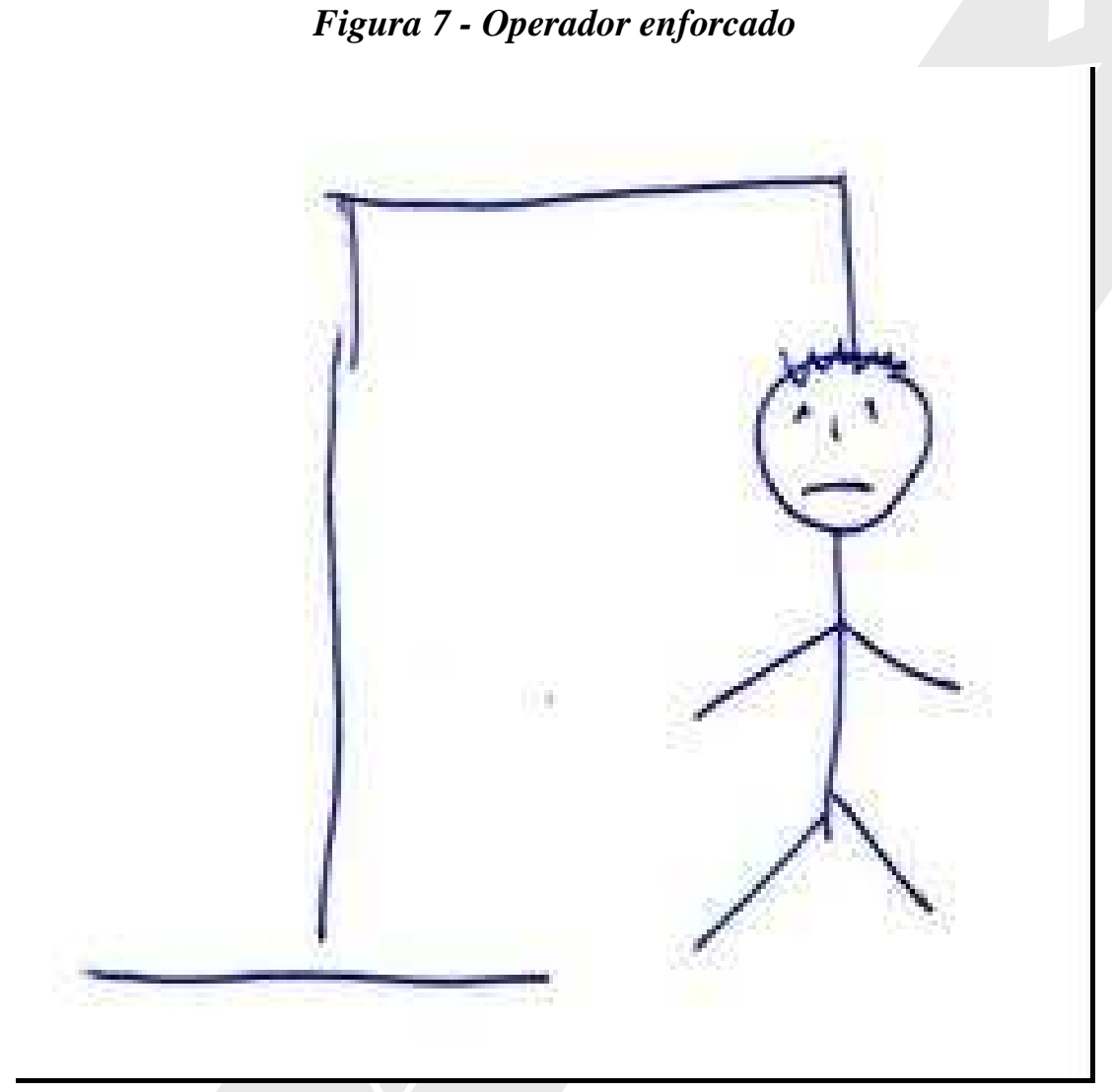

Fonte: Desenho feito por funcionário. Por questões éticas, o nome do autor deve ser preservado.

O conjunto das imagens aqui apresentadas mostra uma organização fortemente marcada por um clima agressivo. De fato, conforme afirma Bourdieu (1999), a violência simbólica tipicamente expressa pela dominação masculina se faz presente em todas as condutas sociais. No entanto, como é possível observar nestas imagens, a dominação se dá não somente sobre a mulher, sendo exercida ainda por homens sobre outros homens, levando à sua autodestruição simbólica e colocando, também, sua masculinidade sob ameaça. O que parece acontecer, conforme diz Bourdieu (1997), é que os homens reproduzem sua conduta sem questionamentos e, podemos acrescentar, sem a consciência de que essa forma se volta contra eles próprios, em face dos dominadores de maior poder. Entretanto, essa é a natureza humana; uma questão interminável, de um mal-estar que sempre vai estar presente na civilização (FREUD, 1997) e que nos motiva constantemente a buscar e a continuar na luta por justiça nas relações humanas, seja nos espaços de produção ou de reprodução.

\section{Comentários finais}

Este artigo sugere e ilustra o quanto a violência está entranhada de uma maneira simbólica nas relações de trabalho. A elaboração dos desenhos feitos a pedido do etnógrafo foi vista, por muito dos que realizaram a 
tarefa na Press, como uma maneira de expressar seu descontentamento contra a organização, uma forma de "aliviar o peito". Nas representações elaboradas pelos seus trabalhadores, a Press é vista como extremamente agressiva com eles, individualmente, ao mesmo tempo em que, isoladamente, estes manifestam sua agressividade contra a empresa, o que indica uma violência simbólica no contexto organizacional analisado. Apesar da violência, não percebi formas coletivas de resistência.

Por se tratar de um estudo feito em outro país, sugere-se que os pesquisadores brasileiros explorem o tema em questão no contexto local. As indicações aqui apresentadas mostram que a violência nas relações de trabalho não se expressa apenas pelas formas evidentes de opressão física e de assédio moral; mas que está disseminada nas formas de conduta no dia a dia, por vezes, imperceptivelmente, dada sua naturalização, como nos sugere Bourdieu (1999). Assim, este estudo pretende indicar a necessidade de melhor se investigar os meios pelos quais a violência se expressa nas organizações, não somente nas formas estudadas e combatidas a partir do conceito de assédio moral (pertinente, sem dúvida; embora, localizado), mas a partir da violência simbólica que parece transpassar todas as relações de trabalho nas organizações.

Este artigo também sugere a importância da utilização de técnicas projetivas em pesquisas etnográficas, como uma forma de ir além das representações verbais. O simples olhar para cada uma das imagens apresentadas indica uma compreensão mais detalhada da realidade organizacional analisada do que a simples apresentação de trechos de entrevistas. As imagens mostradas possibilitam ao leitor uma experiência emocional do clima verificado na gráfica Press. Nesse sentido, o artigo sugere a possibilidade de que pesquisadores do nosso campo possam complementar seus estudos etnográficos valendo-se de técnicas projetivas. 


\section{Referênclas}

AGAR, M. The professional stranger: an informal introduction to ethnography. New York, Academic Press, 1980.

ATKINSON, P. Handbook of ethnography. London ; Thousand Oaks, Calif., SAGE, 2001.

BICALHO, R. Categorias frankfurteanas para uma tipologia da violência nas organizações. In: Anais do Encontro Nacional de Estudos Organizacionais 5, Belo Horizonte, 2008, p. 1-16.

BOURDIEU, P. A dominação masculina. Rio de Janeiro: Record, 1999.

BRYANT, M.; COX, J. W. The telling of violence: organizational changes and atrocity tales. Journal of Organizational Change Management, v.16, n.5, 2003.

BUCHANAN, D. A. The role of photography in organization research: a reengineering case illustration. Journal of Management Inquiry, v.10, n.2, p.151-164, 2001.

BURRELL, G. The sexuality of organization. London: Sage, 1987.

CALDAS, M.; TONELLI, M. J. Casamento, estupro ou dormindo com o inimigo? Interpretando imagens de fusões e aquisições. Organizações e Sociedade, Salvador, v.9, n.23, jan./ abr. 2002.

CASSELL, C, SYMON,G. Qualitative methods in organizational research: a practical guide. Londres: Sage, 1994.

DOUGHERTY, D.; KUNDA, G. Photograph analysis: a method to capture organizational belief systems. In: GAGLIARDI, P. (Ed.). Symbols and artifacts: views of the corporate landscape. Berlin: De Gruyter, 1990. p.185-206.

FLEMMING, P. Sexuality, power and resistancen in the workplace. Organization Studies, v.28, n.2, p. 239-256, 2007.

FOUCAULT, M. Vigiar e punir. Rio de Janeiro: Graal, 1987.

FREITAS, M. E. Assédio moral. São Paulo: Pioneira, 2008.

FREUD, S. 0 mal-estar na civilização. Rio de Janeiro: Zahar, 1997.

HAMMERSLEY, M.; ATKINSON, P. Ethnography: principles in practice. London: Routledge, 1995.

HEARN, J. The organization(s) of violence: men, gender relations, organizations and violences. Human Relations, v.47, n.6, p.731-754, 1994.

; PARKIN, W. Gender, sexuality and violence in organizations: the unspoken forces of organization violations. London: Sage, 2001.

KUNTER, A.; BELL, E. The promise and potential of visual organizational research. M@n@gement, v.9, n.3, p.169-189, 2006.

LINSTEAD, S. Abjection and organization: men, violence and management. Human Relations, n.50, 9, 1997.

MEYER, A. Visual data in organizational research. Organization Science, v.2, n.2, p.218-236, 2001.

NEUMAN, J.; BARON, R. Workplace violence and workplace aggression: evidence concerning specific forms, potential causes, and preferred targets. Journal of Management Studies, v.24, n.3, p.391-419, 1998.

PRESTES MOTTA, F. C. Organização e poder. São Paulo: Atlas, 1986.

SANJEK, R. Fieldnotes: the makings of anthropology. Ithaca, NY: Cornell University Press, 1990.

SCHEFF, T. Male emotions/relations and violence: a case study. Human Relations, v.56, n.6, p.727-749, 2003.

SEGNINI, L. R. P. Ferrovia e ferroviários: uma contribuição para a análise do poder disciplinar na empresa. São Paulo: Cortez, 1982.

SILVA, R.; ALCADIPANI, R. Poder pastoral na Siderúrgica Riograndense. O\&S - Organizações \& Sociedade, Salvador, v.12, n.1, 2004. 
SIQUEIRA, M. et al. Homofobia: violência moral e constrangimentos no ambiente de trabalho. In: Encontro Nacional de Estudos Organizacionais 5, Belo Horizonte, 2008, p1-16.

; PRELORENTZOU, J. Violência moral e pessoas com deficiência: constrangimentos e humilhações no ambiente de trabalho. In: Encontro Nacional de Estudos Organizacionais 5, Belo Horizonte, 2008, p. 1-16.

SOBOLL, L. A. P. (Org.) Violência psicológica e assédio moral no trabalho: pesquisas brasileiras. São Paulo: Casa do Psicólogo, 2008.

SPRADLEY, J. The ethnographic interview. New York: Holt, Rinehart and Winston, 1979.

STRANGLEMAN, T. Ways of (not) seeing work: the visual as a blind spot. In: WES - Work, Employment and Society, v.18, n.1, p.179-192, 2004.

SYMON, G.; CASSELL, C. Qualitative methods and analysis in organizational research. London: Sage, 1998.

THE ECONOMIST (2006) "Who Killed the Newspapers" . 24 de Agosto de 2006.

VAN EMMERIK, H.; EUWEMA, M. C; BAKKER, A. B. Threats of workplace violence and the buffering effect of social support. Educational Administration Quarterly, v.43, n.4, p.399-432, Oct. 2007.

VAN MAANEN, J. The fact and fiction in organizational ethnography. Administrative Science Quarterly, v.24, n.4, p.539-550, 1979.

VERGARA, S. C.; SILVA, J. R. G. 0 significado da mudança: as percepções dos funcionários de uma empresa brasileira diante da expectativa de privatização. Revista Brasileira de Administração Pública, Rio de Janeiro, v.34, n.1, p.79-99, 2000.

WEAVER, W. Dewey or Foucault? Organization and administration as edification and as violence. Organization, v.4, n.1, p.31-48, 1997.

WOOD JR, T.; CALDAS, M. P. Rindo do quê? Como consultores reagem ao humor crítico a sua profissão. O\&tS - Organizações \& Sociedade, v.12, p.83-102, 2005.

ZUBOFF, S. In the age of smart machine: the future of work and power. New York: Basic Books, 1988. 